\title{
Natural Product Extract of Dicksonia sellowiana Induces Endothelium-Dependent Relaxations by a Redox-Sensitive Src- and Akt-Dependent Activation of eNOS in Porcine Coronary Arteries
}

\author{
Yanna D. Rattmann ${ }^{a}$ b Eric Anselm ${ }^{a}$ Jong-Hun Kim ${ }^{a}$ Stéphanie Dal-Ros ${ }^{a}$ \\ Cyril Auger $^{\mathrm{a}}$ Obdulio G. Miguel ${ }^{\mathrm{c}} \quad$ Adair R.S. Santos $^{\mathrm{d}}$ Thierry Chataigneau $^{\mathrm{a}}$ \\ Valérie B. Schini-Kerth ${ }^{a}$ \\ a UMR CNRS 7213, Laboratoire de Biophotonique et Pharmacologie, Faculté de Pharmacie, Université de Strasbourg, \\ Illkirch, France; ${ }^{b}$ Department of Pharmacology, Centro Politécnico, and ${ }^{c}$ Department of Pharmaceutical Sciences, \\ Universidade Federal do Paraná, Curitiba, and ${ }^{\mathrm{d}}$ Department of Physiological Sciences, Universidade Federal de \\ Santa Catarina, Florianópolis, Brazil
}

\section{Key Words}

Dicksonia sellowiana • Porcine coronary artery •

Endothelium $\cdot$ PI3-kinase/Akt pathway $\cdot$ Nitric oxide

\begin{abstract}
Background/Aims: The consumption of polyphenol-rich food is associated with a decreased mortality from coronary diseases. This study examined whether a standardized hydroalcoholic extract of Dicksonia sellowiana (HEDS) triggered endothelium-dependent relaxations in porcine coronary artery rings and characterized the underlying mechanism. Methods: The phosphorylation level of Src, Akt and eNOS was assessed by Western blot analysis, the formation of reactive oxygen species by dihydroethidine staining and the level of eNOS Ser1177 phosphorylation by immunohistochemical staining in sections of coronary arteries. Results: HEDS-induced endothelium-dependent relaxations were strongly reduced by $\mathrm{N} \omega$-nitro-L-arginine, an eNOS inhibitor, and by its combination with charybdotoxin plus apamin, inhibitors of endothelium-derived hyperpolarizing factor-mediated responses. These relaxations were markedly reduced by MnTMPyP (a membrane-permeant mimetic of superox-
\end{abstract}

\section{KARGER}

Fax +4161306 1234

E-Mail karger@karger.ch

www.karger.com
(C) $2012 \mathrm{~S}$. Karger AG, Basel

$1018-1172 / 12 / 0494-0284 \$ 38.00 / 0$

Accessible online at:

www.karger.com/jvr ide dismutase), polyethylene glycol catalase (PEG-catalase; a membrane-permeant analog of catalase), and by wortmannin (an inhibitor of PI3-kinase). HEDS-induced sustained phosphorylation of Akt and eNOS in endothelial cells was abolished by MnTMPyP, PEG-catalase and wortmannin. Oral administration of HEDS induced a significant decrease of mean arterial pressure in spontaneously hypertensive rats. Conclusion: These findings indicate that HEDS caused endothelium-dependent relaxations of coronary artery rings through the redox-sensitive activation of the endothelial $\mathrm{Pl} 3$-kinase/Akt pathway leading to the subsequent activation of eNOS by phosphorylation. HEDS also has antihypertensive properties.

Copyright $\odot 2012$ S. Karger AG, Basel

\section{Introduction}

Cardiovascular disease is the most prevalent disease worldwide and there is intense interest in pharmacological approaches to prevent and reduce the burden of this chronic disease. In this context, several epidemiological studies have indicated an inverse correlation between the 
consumption of polyphenol-rich food such as fruits, vegetables and beverages (wine, grape juices and tea) and the risk of cardiovascular diseases [for reviews, see 1-4].

Some of the potential cardiovascular protective properties of polyphenols have been related to their antioxidant activity. In addition, these compounds have been suggested to decrease the risk of coronary artery disease by several additional mechanisms, i.e. attenuation of the oxidation of low-density lipoprotein $[5,6]$, inhibition of the inflammatory response mediated by nuclear factorkappa B [7], prevention of smooth muscle cell proliferation and migration [8-10], inhibition of platelet aggregation $[11,12]$ and leukocyte adhesion $[13,14]$. Moreover, polyphenols can also exert a direct action on endothelial cells resulting in an enhanced formation of endotheliumderived factors playing a major role in the control of vascular homeostasis, such as nitric oxide (NO) and endothelium-derived hyperpolarizing factor (EDHF) $[1,15-$ 20].

Recently, we have shown that the hydroalcoholic extract of Dicksonia sellowiana (HEDS) Presl. Hook (Dicksoniaceae), a tree fern widely distributed in Central and South America [21, 22], decreases hypertension and induces endothelium-dependent relaxation mediated by activation of muscarinic receptors and stimulation of the NO pathway in rat aortic rings [23]. These effects were attributed to the presence of high amounts of polyphenolic compounds in the extract obtained from $D$. sellowiana leaves. This plant is popularly known as 'xaxim' or 'samambaiaçu' [24, 25] and its leaves are traditionally used to treat scabies, pruritus, parasitic diseases and asthma, mainly among the indigenous population [26]. In Brazil, D. sellowiana is now tested in volunteers for the development of phytomedicinal products against asth$\mathrm{ma}$, and it has also presented beneficial effects on several pathologies such as parasitic and skin diseases and also those related to the cardiovascular system such as hypertension.

The aim of the present study was to determine the vascular and endothelial effects of standardized HEDS leaves on isolated porcine coronary arteries, an important vascular bed, because coronary artery alterations often lead to cardiac diseases. Experiments were performed using isolated coronary artery rings suspended in organ chambers and cultured coronary artery endothelial cells in order to characterize the signaling pathway leading to eNOS activation in response to this extract. In addition, the ability of HEDS to decrease blood pressure in vivo was also investigated in spontaneously hypertensive (SHR) rats.

Effects of D. sellowiana on Porcine Coronary Artery

\section{Methods}

Plant Material and Preparation of HEDS

D. sellowiana leaves, harvested in the metropolitan region of Curitiba (Brazil), were identified in the Department of Botany of the Federal University of Paraná (Curitiba, PR, Brazil). Voucher specimens were deposited at the herbarium of the university under No. 46579.

The procedures used to prepare and analyze HEDS have been described previously [23]. Briefly, $10 \mathrm{~g}$ of powdered dry plant leaves was kept in a glass cartridge with a porous plate No. 1 and connected to a modified Soxhlet apparatus, where $200 \mathrm{ml}$ of $85 \%$ aqueous ethanol was added for $3 \mathrm{~h}$. The extract was concentrated to $100 \mathrm{ml}$ and filtrated using a $0.45 \mu \mathrm{m}$ membrane filter. The calculated yield of the HEDS was $0.0341 \mathrm{~g} / \mathrm{ml}$. The standardized dry extract of $D$. sellowiana leaves was produced by the Humanus Biobotânica Indústria e Comércio LTDA (lot 0236/05) and supplied by the Natureza Pura Laboratório de Pesquisas Científicas LTDA. The phenolic content of HEDS was determined by the Folin-Ciocalteu method and corresponds to $494.2 \mathrm{mg} / \mathrm{g}$ gallic acid equivalent. High-performance liquid chromatography-photodiode array detection (HPLC-DAD) analysis showed that the extract contained $6.3 \mathrm{mg} / \mathrm{g}$ gallic acid, $8.7 \mathrm{mg} / \mathrm{g}$ protocatechuic acid, 17.1 $\mathrm{mg} / \mathrm{g}$ chlorogenic acid, $28.0 \mathrm{mg} / \mathrm{g}$ coumaric acid, $12.9 \mathrm{mg} / \mathrm{g}$ ferulic acid, $8.45 \mathrm{mg} / \mathrm{g}$ sinapic acid and $18.3 \mathrm{mg} / \mathrm{g}$ cinnamic acid. Traces of other compounds were also detected but remained unidentified.

\section{Reagents}

All substances were of analytic grade. Apamin, charybdotoxin and iberiotoxin were from Latoxan. Tram-34, calmidazolium, atropine, superoxide dismutase (SOD), catalase, polyethylene glycol catalase (PEG-catalase), indomethacin, bradykinin, dihydroethidine (DHE), N $\omega$-nitro-L-arginine (L-NA), KN-93 $\{2-[\mathrm{N}-(2-$ hydroxyethyl)-N-(4-methoxybenzenesulfonyl)] amino-N-(4chlorocinnamyl)-N-methylbenzylamine $\}$ and $\mathrm{N}$-acetyl-L-cysteine (NAC) were obtained from Sigma. Wortmannin and the SOD mimetic Mn(III)tetrakis(1-methyl-4-pyridyl)porphyrin (MnTMPyP) were from Alexis Chemicals. U46619 (9,11-dideoxy- $9 \alpha$-methanoepoxy prostaglandin $\mathrm{F}_{2 \alpha}$ ) was obtained from Cayman Chemical and compound C and PP2 (4-amino-5-(4chlorophenyl)-7-(t-butyl)pyrazolo [3,4-d]pyrimidine) were from Calbiochem. The tested substances were dissolved in Krebs bicarbonate or $10 \%$ (vol/vol) dimethyl sulfoxide. The solution of the HEDS was prepared in Krebs solution directly before use.

Preparation of Rings of Porcine Coronary Arteries

Hearts from pigs were collected from a local slaughterhouse and the left anterior descending coronary artery was dissected free of fat and connective tissue and cut into $4 \mathrm{~mm}$ rings. The rings were then mounted on two stainless steel hooks in $10 \mathrm{ml}$ organ baths. One of these hooks was attached to a force transducer to measure changes in isometric tension and coupled to an amplifier and computer for data collection. In experiments requiring endothelium-denuded rings, the endothelium was removed by rubbing the intimal surface with a pair of forceps. Tissues were maintained at $37^{\circ} \mathrm{C}$ in oxygenated $\left(95 \% \mathrm{O}_{2} / 5 \% \mathrm{CO}_{2}\right)$ Krebs bicarbonate solution (composition in $\mathrm{mM}: \mathrm{NaCl} \mathrm{119,} \mathrm{KCl} 4.7, \mathrm{KH}_{2} \mathrm{PO}_{4}$ 1.18, $\mathrm{MgSO}_{4} 1.18, \mathrm{CaCl}_{2} 1.25, \mathrm{NaHCO}_{3} 25$, and D-glucose 11, $\mathrm{pH}$ 7.4) at a resting tension of $5 \mathrm{~g}$. Rings were allowed to equilibrate

J Vasc Res 2012;49:284-298 
for at least $60 \mathrm{~min}$, a period during which the tension was adjusted and the bathing solution was periodically changed.

\section{Vascular Reactivity Studies}

Following equilibration, the viability of each coronary ring was determined by repetitive contraction with $\mathrm{KCl}(80 \mathrm{mM})$. After a 30 min washout period, rings were contracted with the thromboxane mimetic U46619 (1-60 nM) to about $80 \%$ of the maximal contraction and then relaxed with bradykinin $(0.3 \mu \mathrm{M})$ to check the presence of a functional endothelium. After the removal of these drugs by repeated washings, the rings were contracted under the same conditions as described above before the addition of HEDS (from 0.1 to $100 \mu \mathrm{g} / \mathrm{ml}$ ). In some experiments, the rings were exposed to an inhibitor for $30 \mathrm{~min}$ before the addition of U46619.

In another set of experiments, cumulative contractile responses induced by $\mathrm{U} 46619(1 \mathrm{nM}$ to $1 \mu \mathrm{M})$ were obtained in the presence of HEDS $(100 \mu \mathrm{g} / \mathrm{ml})$ under different time conditions: (a) HEDS incubated during 5, 30, 60 min or $3 \mathrm{~h}$ before the addition of U46619 in the presence of the extract; (b) HEDS incubated for only $5 \mathrm{~min}$ before washing and a subsequent 25, $55 \mathrm{~min}$ or $2 \mathrm{~h} 55 \mathrm{~min}$ waiting period before the contraction was induced by U46619 in the absence of the extract, and (c) both previous conditions in the presence of L-NA $(100 \mu \mathrm{M})$, an NO synthase inhibitor.

\section{Determination of Vascular Reactive Oxygen Species \\ Formation}

The redox-sensitive fluorescent dye DHE was used to evaluate the in situ formation of reactive oxygen species (ROS) by the use of a method described by Miller et al. [27]. DHE permeates freely into cells and in the presence of ROS is oxidized to ethidium which is trapped by intercalating with the DNA. Porcine coronary rings (5 to $6 \mathrm{~mm}$ length) from the control group or treated with either HEDS $(100 \mu \mathrm{g} / \mathrm{ml})$, HEDS plus SOD $(500 \mathrm{U} / \mathrm{ml})$, catalase $(500 \mathrm{U} / \mathrm{ml}), \mathrm{MnTMPyP}(100 \mu \mathrm{M})$, PEG-catalase $(500 \mathrm{U} / \mathrm{ml})$ or NAC (10 mM) were embedded in OCT compound (Tissue-Tek; Qiagen, Hilden, Germany), and frozen in a liquid nitrogen bath before cryostat sections. These unfixed frozen coronary artery rings were cut into $25-\mu \mathrm{m}$-thick sections and placed on poly-Llysine-coated microscope slides. DHE $(2.5 \mu \mathrm{M})$ was applied to all tissue sections on the slide, which was then incubated in a lightprotected humidified chamber at $37^{\circ} \mathrm{C}$ for 30 min before being sealed with a coverslip. Images were obtained with a Bio-Rad MRC-1024 laser-scanning confocal microscope equipped with a krypton/argon laser. Laser settings were identical for the acquisition of images from control and HEDS-treated groups. Ethidium was excited at $488 \mathrm{~nm}$ and fluorescence was detected with a 585 $\mathrm{nm}$ longpass filter.

\section{Immunohistochemical Determination of Phosphorylated} eNOS

Porcine coronary arteries were removed from the porcine hearts, embedded in OCT compound and frozen in liquid nitrogen. The frozen coronary arteries were cryosectioned at $14 \mu \mathrm{m}$. Sections were air-dried for $1 \mathrm{~h}$ and stored at $-80^{\circ} \mathrm{C}$ until use. The sections were placed in $4 \%$ paraformaldehyde for fixation, and thereafter treated with $10 \%$ serum in PBS containing $0.1 \%$ BSA and $0.05 \%$ Tween-20 for 45 min to block nonspecific binding. After rinsing, the sections were then incubated overnight at $4^{\circ} \mathrm{C}$ with control nonimmune serum or an antibody directed against phosphorylated eNOS. The antibody used was a purified rabbit polyclonal against phosphorylated Ser1177 eNOS (sc-21871, 1:100 dilution; Santa Cruz Biotechnology). Sections were washed with PBS, incubated with the secondary antibody (Alexa Fluor 633-labeled anti-rabbit IgG, 1:200 dilution; Cell Signaling Technology), diluted in the same buffer for $2 \mathrm{~h}$ at room temperature in the dark and washed before being mounted and coverslipped. The sections were examined under a confocal microscope. For analysis of immunostaining intensity in coronary artery sections, we measured the fluorescence values of 6 arteries per group (on 3 randomly selected areas for each section). The fluorescence quantifications were assessed using the software ImageJ (NIH public domain software).

\section{Culture of Porcine Coronary Artery Endothelial Cells}

Segments of porcine coronary arteries were flushed with PBS without calcium to remove the remaining blood. Thereafter, endothelial cells were isolated by collagenase treatment (type I, Worthington, $1 \mathrm{mg} / \mathrm{ml}$ for $15 \mathrm{~min}$ at $37^{\circ} \mathrm{C}$ ), and cultured in culture dishes containing MCDB 131 medium (Invitrogen) supplemented with $15 \%$ fetal calf serum, penicillin $(100 \mathrm{U} / \mathrm{ml})$, streptomycin $(100 \mathrm{U} / \mathrm{ml})$, fungizone $(250 \mu \mathrm{g} / \mathrm{ml})$ and L-glutamine (2 mM) (all from Cambrex) and grown for 48-72 h. All experiments were performed with confluent cultures of cells used at first passage. Cells were exposed to a serum-free culture medium in the presence of $0.1 \%$ bovine serum albumin (QBiogene) for $6 \mathrm{~h}$ prior to treatment.

\section{Western Blot Analysis}

The level of phosphorylation of Src, Akt and endothelial eNOS was determined in cultured endothelial cells using Western blot analysis. After treatment, the endothelial cells were washed twice with PBS and then lysed in an extraction buffer of the following composition in mM: Tris/ $\mathrm{HCl} 20$ (pH 7.5; QBiogene), $\mathrm{NaCl} 150$, $\mathrm{Na}_{3} \mathrm{VO}_{4} 1$, sodium pyrophosphate $10, \mathrm{NaF} 20$, okadaic acid 0.01 (Sigma), a tablet of protease inhibitor (Roche) and 1\% Triton X-100 (QBiogen). Total proteins $(20 \mu \mathrm{g})$ were separated on $8 \%$ SDS-polyacrylamide (Sigma) gels at $70 \mathrm{~V}$ for $2.5 \mathrm{~h}$. Separated proteins were transferred electrophoretically onto polyvinylidine difluoride membranes (Amersham) at $100 \mathrm{~V}$ for $120 \mathrm{~min}$. Membranes were blocked with a blocking buffer containing 3\% bovine serum albumin for p-Akt and p-eNOS, and I-block for p-Src, Tris-buffered saline solution (Biorad) and $0.1 \%$ Tween 20 (Sigma) for $1 \mathrm{~h}$. For detection of phosphorylated proteins, membranes were incubated with the respective primary antibody ( $\mathrm{p}$-Src Tyr418, Biosource; p-Akt Ser473 and p-eNOS Ser1177, Cell Signaling Technology; dilution 1:1,000) overnight at $4^{\circ} \mathrm{C}$. After washing, membranes were incubated with the secondary antibody (peroxidase-labeled anti-rabbit IgG, dilution 1:5,000; Cell Signaling Technology) at room temperature for $60 \mathrm{~min}$. Prestained markers (Invitrogen) were used for molecular mass determinations. Immunoreactive bands were detected by enhanced chemiluminescence (Amersham). Ponceau staining was performed to verify the quality of the transfer and equal amounts of proteins in each lane. Densitometric analyses were performed with the software ImageJ.

\section{Antihypertensive Effects of HEDS}

The putative dose-dependent antihypertensive effect of HEDS was examined in SHR rats. The extract was administered by gavage at $30-300 \mathrm{mg} / \mathrm{kg}$. After a 1 -hour treatment period, the rats 


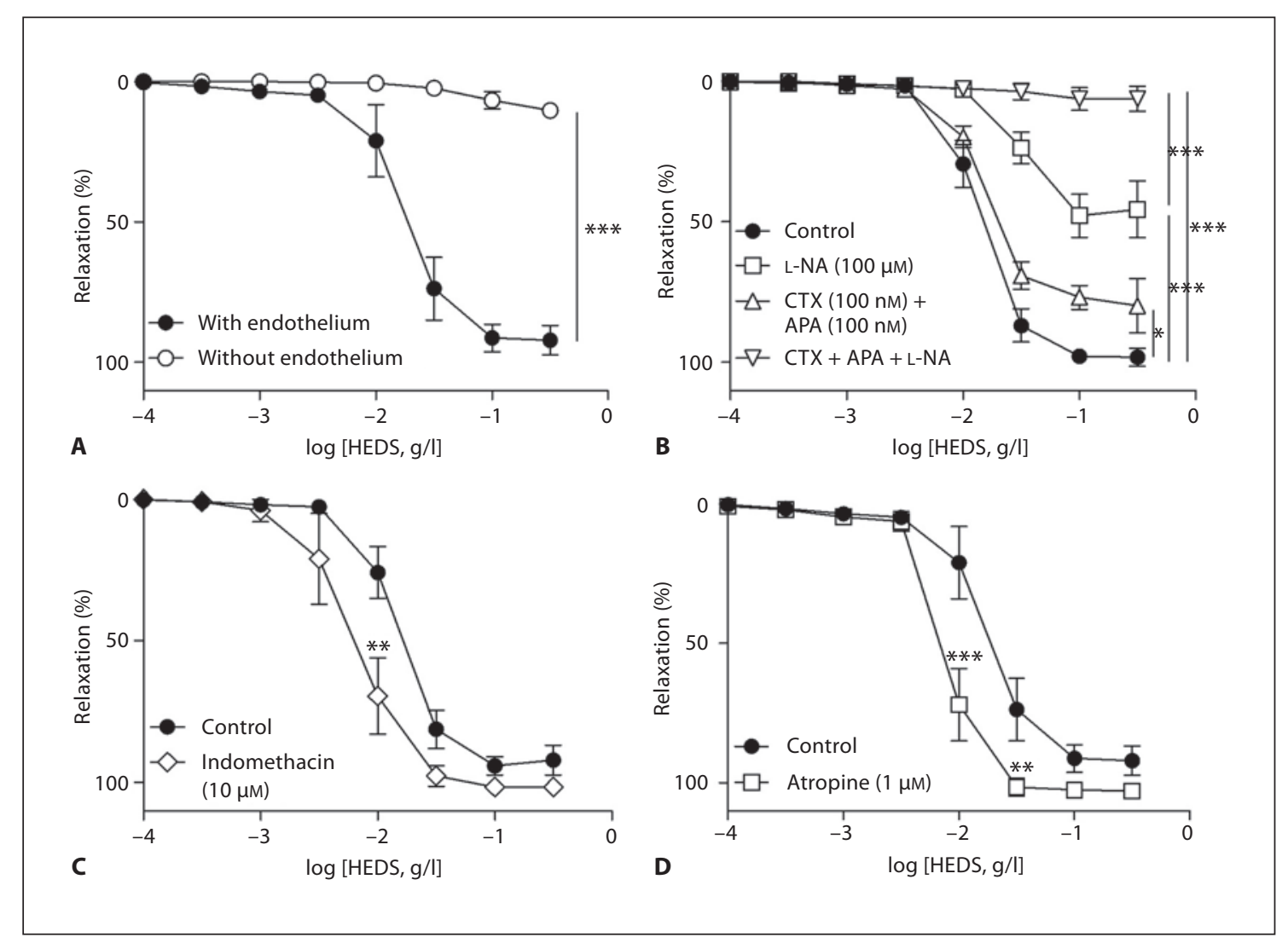

Fig. 1. Characterization of HEDS-induced relaxations in isolated porcine coronary artery rings. Intact and endothelium-denuded rings were contracted with U46619 before the addition of cumulative concentrations of HEDS. A Endothelium-dependent relaxations induced by HEDS. B Effect of L-NA (100 $\mu \mathrm{M})$, apamin (APA, 100 $\mathrm{nM})$ plus charybdotoxin (CTX, $100 \mathrm{nM}$ ), and the combination of L-NA and apamin plus charybdotoxin on HEDS-induced relaxations. C Effect of indomethacin $(10 \mu \mathrm{M})$ on HEDS-induced relaxations in coronary artery rings with endothelium. D Relaxant effect of HEDS in the presence of atropine $(1 \mu \mathrm{M})$ in intact arteries. Results are shown as means \pm SEM of 6 different experiments. ${ }^{*} \mathrm{p}<0.05,{ }^{* *} \mathrm{p}<0.01$ and ${ }^{* * *} \mathrm{p}<0.001$ for inhibitory effect versus control.

were anesthetized with ketamine $(100 \mathrm{mg} / \mathrm{kg})$ and xylazine $(20$ $\mathrm{mg} / \mathrm{kg})$, given by intramuscular route. A polyethylene tube (PE 50) filled with heparinized saline was catheterized into the left carotid artery. The catheter was connected via a pressure transducer to a MacLab ${ }^{\circledR}$ recording system for online measurement of blood pressure. During the measurement period the rats were placed on a warm bed maintained at $36^{\circ} \mathrm{C}$.

\section{Statistical Analysis}

The results are expressed as means \pm SEM of 3-8 experiments. Statistical significance was determined through a one-way analysis of variance (ANOVA) followed by Bonferroni's test or with Student's t test for paired data as required. Statistical analysis was performed using GraphPad Prism version 5.00 for Windows (GraphPad Software, San Diego, Calif., USA). Values of $\mathrm{p}<0.05$ were considered statistically significant.

Effects of D. sellowiana on Porcine Coronary Artery

\section{Results}

HEDS Induces Endothelium-Dependent Relaxations in Coronary Artery Rings

The addition of cumulative concentrations of HEDS on isolated porcine coronary artery rings contracted with U46619 induced concentration-dependent relaxations in endothelium-intact but not in endothelium-denuded preparations (fig. 1A). The endothelium-dependent relaxations started at concentrations greater than $1 \mu \mathrm{g} / \mathrm{ml}$ and reached a near maximal value at $100 \mu \mathrm{g} / \mathrm{ml}\left(\mathrm{E}_{\max }=95.2\right.$ $\pm 3.2 \%)$. Relaxations to HEDS were significantly reduced by L-NA $(100 \mu \mathrm{M})$, an inhibitor of eNOS (approx. 54\% of inhibition of $\mathrm{E}_{\max }$ ), minimally affected (around $18 \%$ ) by the combination of charybdotoxin (100 nM) plus apamin 


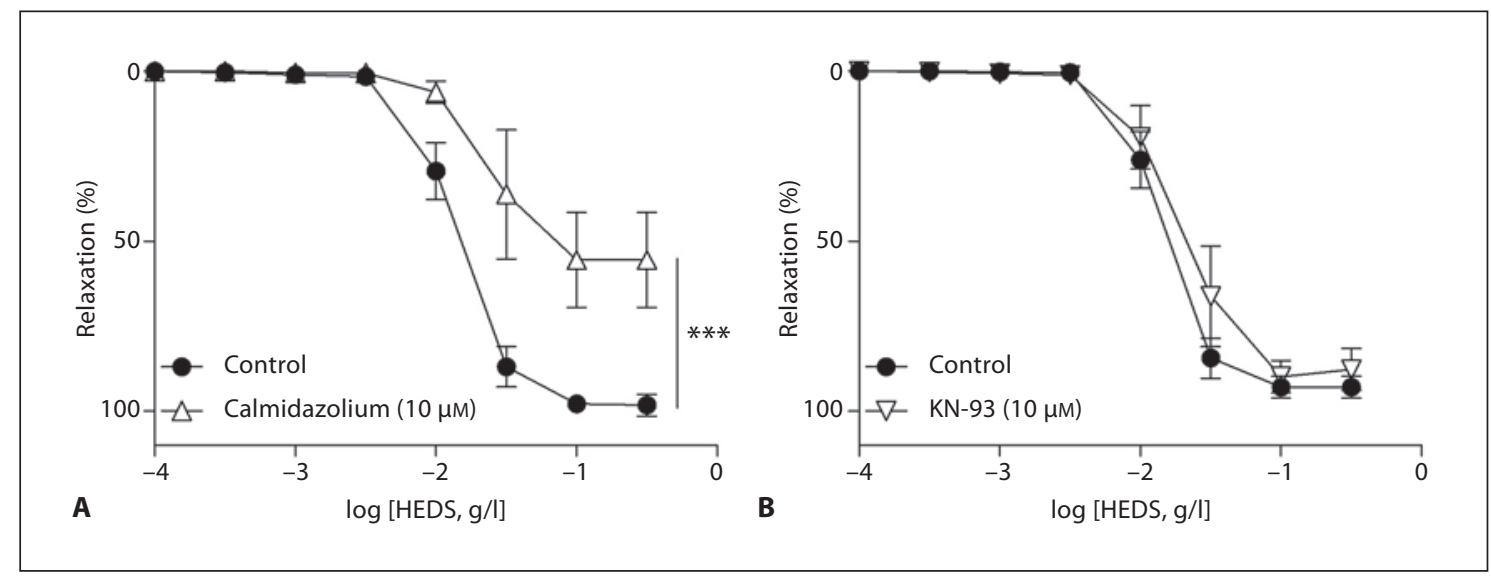

Fig. 2. Role of calmodulin and CaMKII on endothelium-dependent relaxations induced by HEDS in intact coronary artery rings. Rings were incubated with either calmidazolium (10 $\mu \mathrm{M})$ (A) or KN-93 (10 $\mu \mathrm{M})$ (B) for 30 min before the contraction with U46619 and subsequent addition of HEDS. Results are shown as means \pm SEM of 6 different experiments. ${ }^{* *} \mathrm{p}<0.001$ for inhibitory effect versus control.

(100 nM), two inhibitors of EDHF-mediated responses, and almost abolished ( $94 \%$ of inhibition) by the combination of L-NA with charybdotoxin plus apamin (fig. 1B). Indomethacin $(10 \mu \mathrm{M})$ induced a leftward shift of the concentration-response curve for HEDS-induced relaxations without affecting the maximal relaxation (fig. 1C). Tram34 plus apamin-resistant relaxations to HEDS were unaffected by iberiotoxin, a selective inhibitor of $\mathrm{BK}_{\mathrm{Ca}}$ channels ( $\mathrm{n}=8$, data not shown), indicating that these channels are unlikely to be involved. Atropine $(1 \mu \mathrm{M})$, a selective muscarinic receptor antagonist, induced a significant potentiation of the relaxations elicited by HEDS (fig. 1D) without significantly affecting the maximal relaxation. Altogether, these findings indicate that HEDS causes endothelium-dependent relaxations, mainly dependent on an L-NA-sensitive component and also, to some extent, on an EDHF component and rule out the involvement of muscarinic receptors. In addition, prostanoids seem to oppose the relaxant effect induced by HEDS.

\section{Role of Calmodulin and Calmodulin-Dependent}

Kinase II in HEDS-Induced Relaxations

In endothelial cells, eNOS has been shown to be a constitutive and $\mathrm{Ca}^{2+} / \mathrm{CaM}$-dependent enzyme. An increase in the intracellular-free $\mathrm{Ca}^{2+}$ concentration, as observed following receptor-dependent and receptor-independent stimulation, enhances endothelial NO formation and elicits vasodilatation. eNOS can be phosphorylated and activated by a calmodulin-dependent enzyme such as calmodulin-dependent kinase II (CaMKII) [28]. Incubation of rings with calmidazolium $(10 \mu \mathrm{M})$, a calmodulin inhibitor, caused a partial reduction of the relaxations induced by HEDS (approximately $40 \%$ of inhibition of $\mathrm{E}_{\max }$ ) (fig. $2 \mathrm{~A}$ ), whereas KN-93 $(10 \mu \mathrm{M})$, a selective CaMKII inhibitor, was without effect (fig. 2B). These results indicate that HEDSinduced relaxations partially involve eNOS activation by a calmodulin-dependent but not a CaMKII-dependent mechanism. Treatment of coronary artery rings with compound $\mathrm{C}(50 \mu \mathrm{M})$, an inhibitor of AMP-activated protein kinase, did not significantly affect endothelium-dependent relaxations to HEDS at low concentrations and even potentiated them at 1 and $3 \mu \mathrm{g} / \mathrm{ml}$ indicating that AMPactivated protein kinase does not play a role in HEDS-induced eNOS activation ( $\mathrm{n}=8$, data not shown).

\section{Role of ROS, Src Kinase and the PI3-Kinasel}

Akt Pathway in HEDS-Induced Relaxations

Recent findings indicate that polyphenolic compounds can induce $\mathrm{NO}$-mediated relaxations in porcine coronary arteries by a mechanism involving the endothelial production of ROS and activation of the PI3-kinase/ Akt pathway $[15,20]$ leading to eNOS phosphorylation. The consequent activation of eNOS through this pathway has been found to occur even in a $\mathrm{Ca}^{2+}$-free medium [29]. Therefore, experiments were performed using SOD (500 $\mathrm{U} / \mathrm{ml}), \operatorname{MnTMPyP}(100 \mu \mathrm{M})$, a membrane-permeant SOD mimetic, catalase $(500 \mathrm{U} / \mathrm{ml})$ and PEG-catalase (500 U/ $\mathrm{ml}$ ), a membrane-permeant catalase mimetic, to determine whether a ROS signaling pathway is involved in HEDS-induced relaxations. The relaxations induced by 


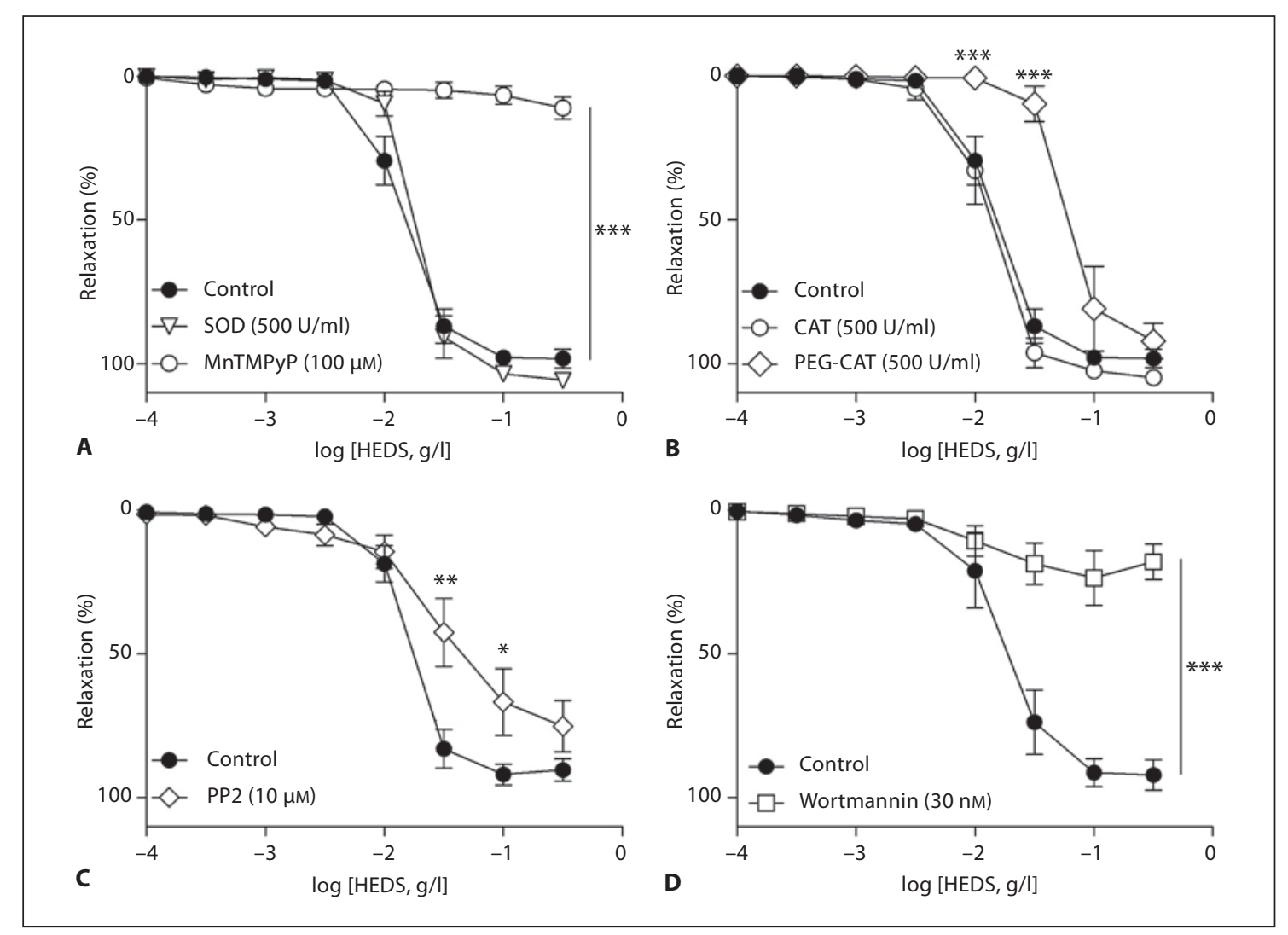

Fig. 3. Role of the redox-sensitive Src kinase and the PI3-kinase/Akt pathway in HEDS-induced endotheliumdependent relaxations. Coronary artery rings with endothelium were incubated with native SOD (500 U/ml) or MnTMPyP $(100 \mu \mathrm{M})$, a cell permeable SOD mimetic (A), native catalase (CAT, $500 \mathrm{U} / \mathrm{ml}$ ) or PEG-catalase (PEGCAT, $500 \mathrm{U} / \mathrm{ml})$, a membrane-permeant analog of catalase (B), the Src kinase inhibitor PP2 (10 $\mu \mathrm{M})(\mathbf{C})$ and the PI3-kinase inhibitor wortmannin $(30 \mathrm{nM})$ (D) for $30 \mathrm{~min}$ before contraction to U46619 and subsequent relaxation to HEDS. Results are shown as means \pm SEM of 6 different experiments. ${ }^{*} \mathrm{p}<0.05,{ }^{* *} \mathrm{p}<0.01$ and *** $\mathrm{p}<0.001$ for inhibitory effect versus control.

HEDS $(0.1-100 \mu \mathrm{g} / \mathrm{ml})$ were markedly reduced by the membrane-permeant SOD mimetic MnTMPyP (approx. $89 \%$ of inhibition of $\left.E_{\max }\right)$, and partially inhibited by the cell-permeable PEG-catalase, whereas native SOD and native catalase did not have such an effect (fig. 3A, B, respectively).

Moreover, it has been shown that Src, a redox-sensitive kinase, acts as an upstream activator of the PI3-kinase/ Akt pathway leading to the polyphenol-induced eNOS activation [30, 31]. Experiments were performed, therefore, to determine the role of the Src kinase/PI3-kinase/ Akt pathway in relaxations to HEDS. Inhibition of Src kinase with PP2 $(10 \mu \mathrm{M})$ partially but significantly reduced relaxations to HEDS (fig. 3C) and inhibition of the PI3-kinase by wortmannin ( $30 \mathrm{nM}$ ) almost abolished relaxations to HEDS ( $80 \%$ of inhibition) (fig. 3D).

Effects of D. sellowiana on Porcine Coronary Artery
HEDS Stimulates the Formation of ROS and eNOS Ser1177 Phosphorylation in Sections of Porcine Coronary Arteries

As indicated previously, polyphenols cause a pro-oxidant response in endothelial cells which in turn causes activation of the PI3-kinase/Akt pathway leading to NO formation [1]. To evaluate the ROS production induced by HEDS, sections of porcine coronary arteries were exposed to DHE and the ability of HEDS to stimulate the formation of superoxide anions was evaluated in situ in the presence of different treatments. In comparison to control (fig. 4A, a), HEDS (100 $\mu \mathrm{g} / \mathrm{ml})$ consistently increased the fluorescence signal predominantly at the endothelial layer (fig. 4A, b). Treatment of artery sections with native SOD $(500 \mathrm{U} / \mathrm{ml})$ or catalase $(500 \mathrm{U} / \mathrm{ml}) \mathrm{did}$ not affect the fluorescence signal (fig. 4A, c, d). How- 

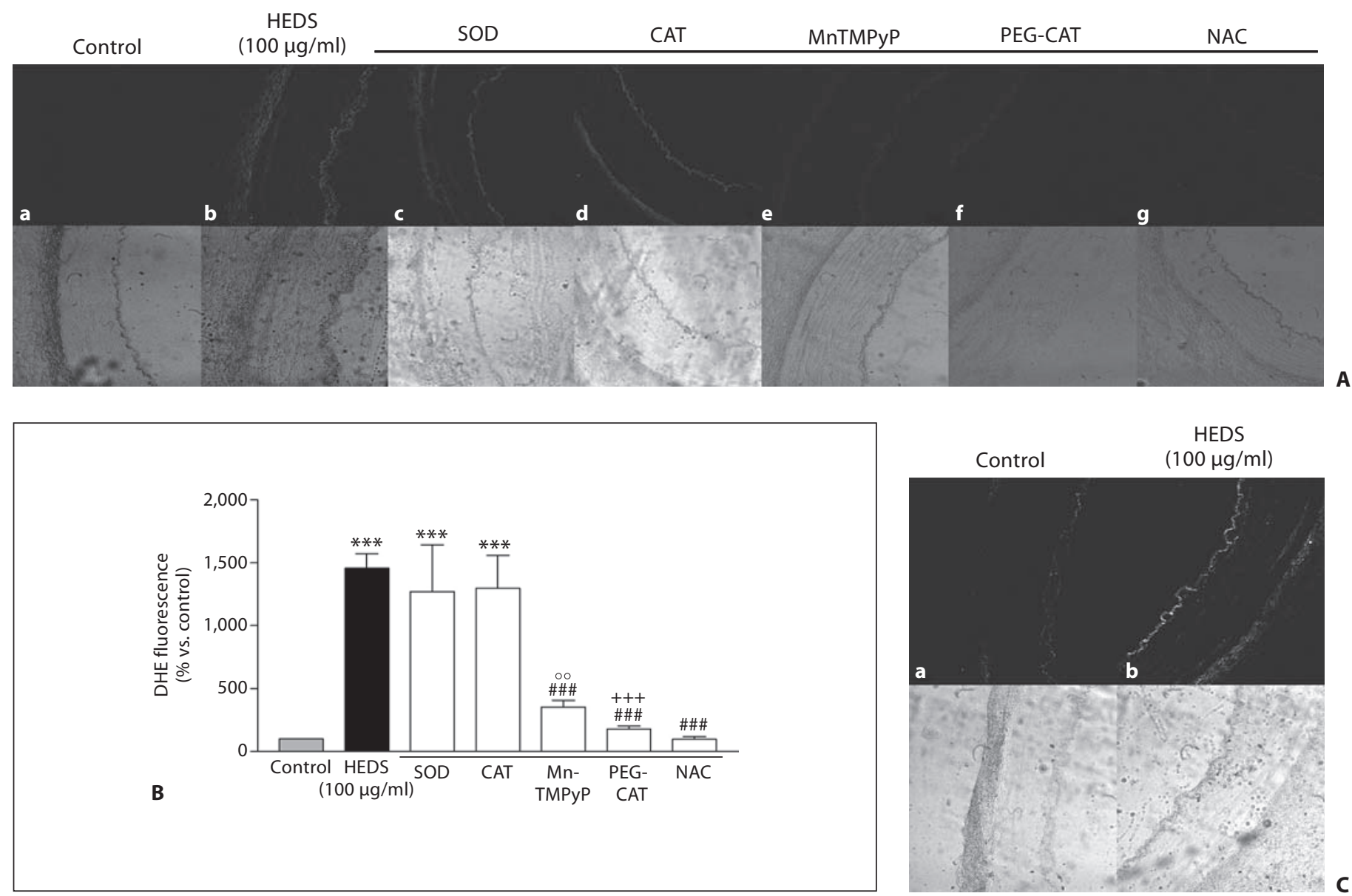

Fig. 4. HEDS induces the formation of ROS in sections of porcine coronary arteries and stimulates Ser1177 eNOS phosphorylation. A Sections of arteries loaded with $10 \mu \mathrm{M} \mathrm{DHE}$ were either untreated (a) or exposed to HEDS (b) in the presence of SOD (500 U/ml) (c), catalase (CAT, $500 \mathrm{U} / \mathrm{ml})(\mathbf{d}), \mathrm{MnTMPyP}(100 \mu \mathrm{M})(\mathbf{e})$, PEG-catalase (PEG-CAT, $500 \mathrm{U} /$ $\mathrm{ml})(\mathbf{f})$ or NAC (10 mM) (g) for $30 \mathrm{~min}$. DHE fluorescence was monitored over $10 \mathrm{~min}$ using a confocal microscope. B Corresponding cumulative data. C Immunohistochemical staining in coronary artery sections using antibody against phosphorylated Ser1177 eNOS. Representative original microphotographs showing an increased eNOS phosphorylation signal after treatment with HEDS $(100 \mu \mathrm{g} / \mathrm{ml}, 10 \mathrm{~min})(\mathbf{b})$ compared to control (a). D Corresponding cumulative data. Results are shown as means \pm SEM of 4 or 6 different experiments. ${ }^{* *} \mathrm{p}<0.01$ and ${ }^{* *} \mathrm{p}<0.001$ versus control; ${ }^{\# \# \#} \mathrm{p}<0.001$ versus HEDS; ${ }^{\circ} \mathrm{p}<0.01$ versus SOD; ${ }^{+++} \mathrm{p}<0.001$ versus CAT.

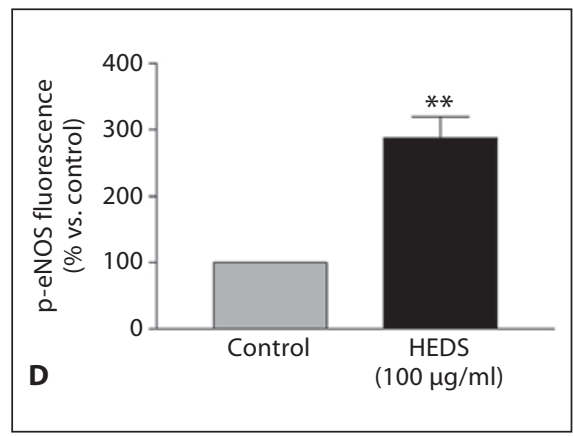

ever, the membrane-permeant substances MnTMPyP $(100 \mu \mathrm{M})$ and PEG-catalase $(500 \mathrm{U} / \mathrm{ml})$ and the antioxidant $\mathrm{N}$-acetylcysteine (NAC, $10 \mathrm{mM}$ ) abolished the HEDS-induced endothelial ROS production (fig. 4A, $\mathrm{e}-\mathrm{g})$.

In endothelial cells, eNOS activation can occur by Akt-dependent phosphorylation of eNOS at Ser1177 [29]. Therefore, to assess the effects of HEDS on eNOS activation by Ser1177 phosphorylation, immunohistochemical experiments were performed in coronary artery sections using an antibody directed against phosphorylated eNOS Ser1177. HEDS $(100 \mu \mathrm{g} / \mathrm{ml}, 10 \mathrm{~min})$ induced a strong increase in phosphorylation of eNOS Ser1177 (fig. 4C, b) compared to basal conditions (fig. 4C, a). Densitometric quantification showed a significant increase in staining intensity for phosphorylated eNOS following HEDS stimulation up to $287 \pm 32 \%$ (fig. $4 \mathrm{D}$ ). 


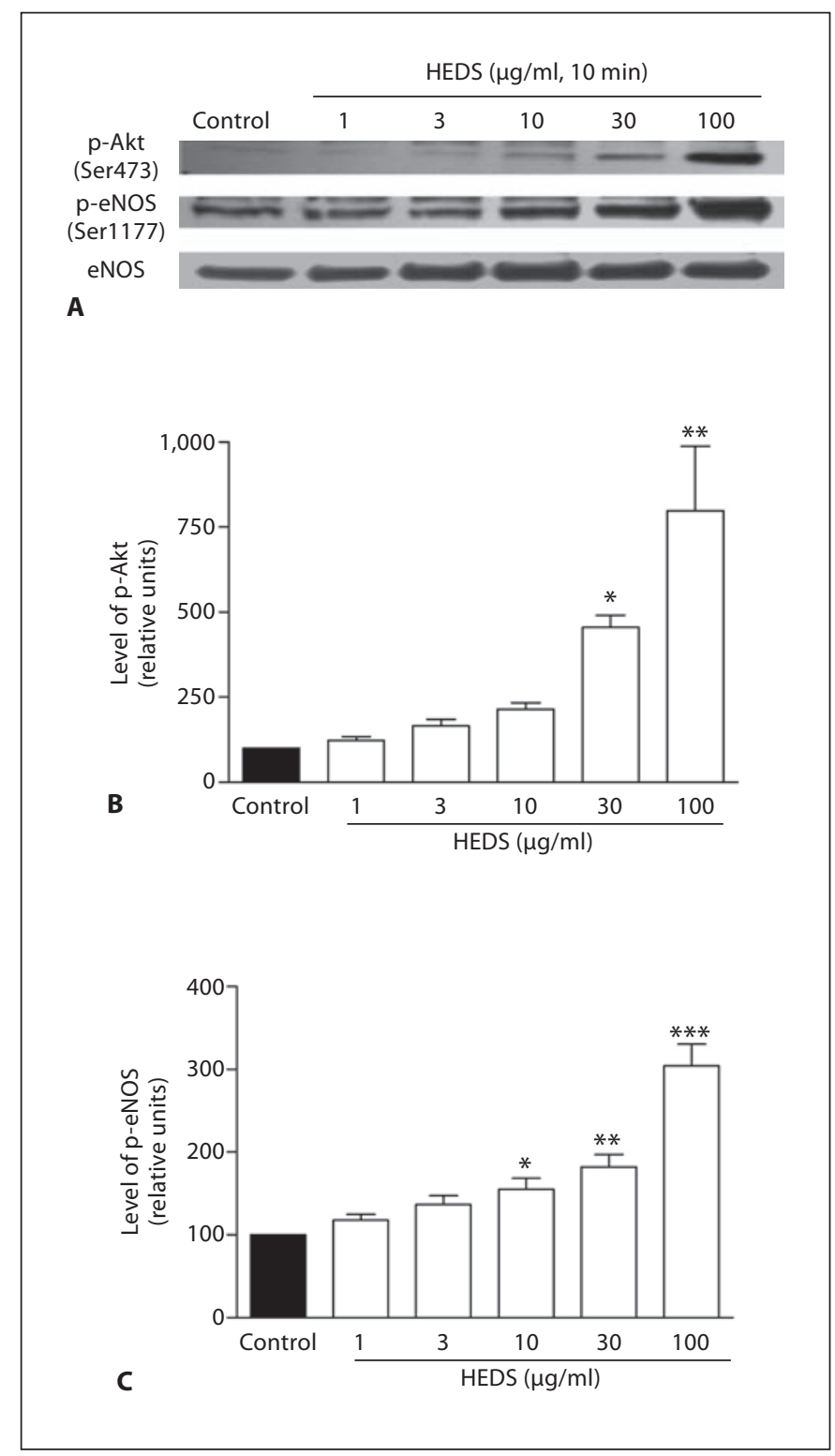

Fig. 5. HEDS causes a concentration-dependent phosphorylation of Akt at Ser473 (B) and eNOS at Ser1177 (C) in cultured porcine coronary artery endothelial cells. Results are shown as means \pm SEM of 3-4 different immunoblots $(\mathbf{A}) .{ }^{*} \mathrm{p}<0.05,{ }^{* *} \mathrm{p}<0.01$ and *** $\mathrm{p}<0.001$ for inhibitory effect versus control.

HEDS Causes the Redox-Sensitive Activation of Src with Subsequent PI3-Kinase/Akt-Dependent Phosphorylation of eNOS

To better characterize the signaling pathway involved in eNOS activation in response to HEDS, levels of phosphorylated Src, Akt and eNOS were assessed in endothelial cells by Western blot analysis.

Effects of D. sellowiana on Porcine Coronary Artery

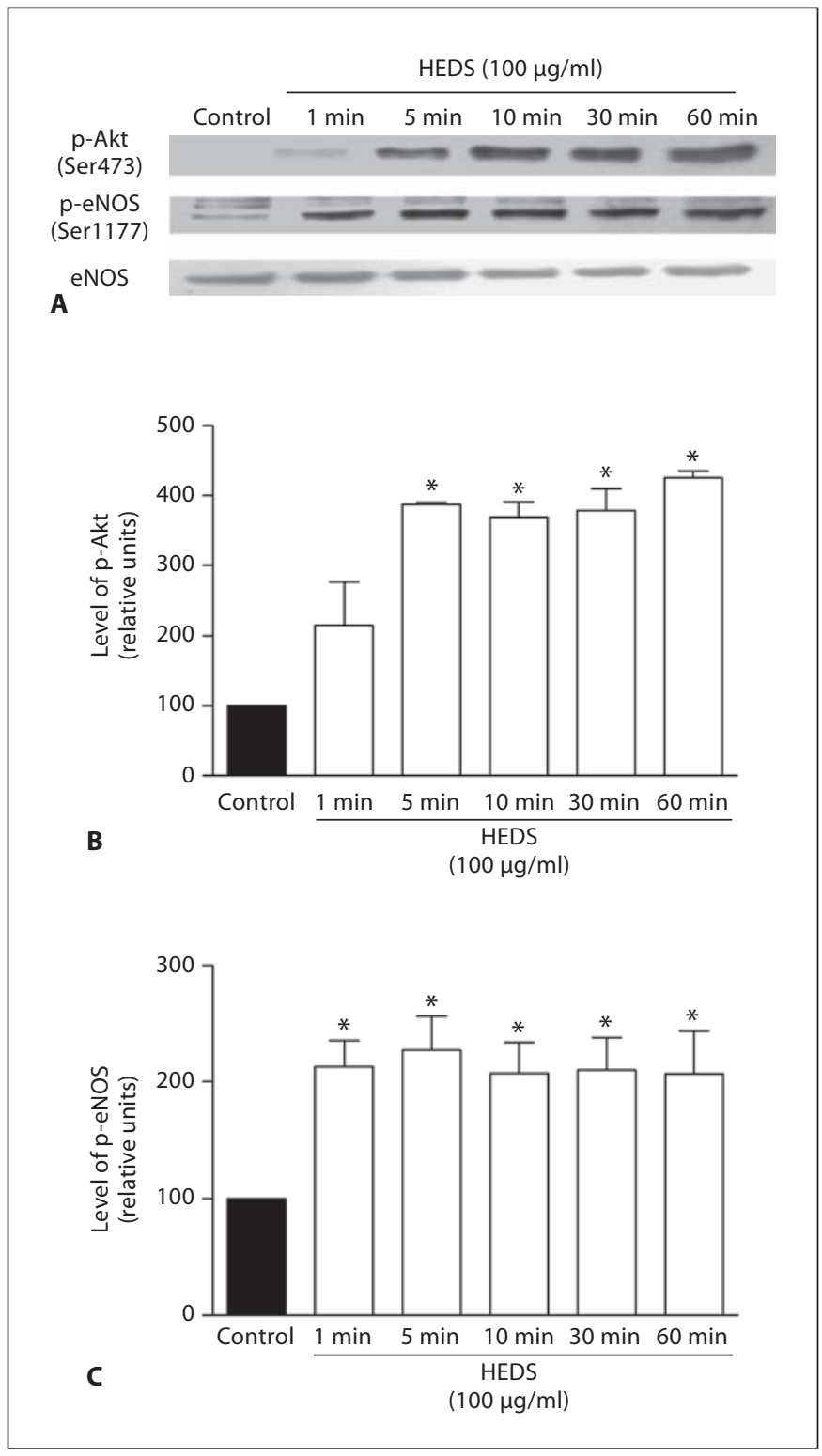

Fig. 6. HEDS causes a time-dependent phosphorylation of Akt at Ser473 (B) and eNOS at Ser1177 (C) in endothelial cells. Results are shown as means \pm SEM of 3-4 different immunoblots (A). ${ }^{*} \mathrm{p}<0.05$ for inhibitory effect versus control.

HEDS (1-100 $\mu \mathrm{g} / \mathrm{ml}, 10 \mathrm{~min})$ evoked the concentration-dependent phosphorylation of Akt at Ser473 and eNOS at Ser1177 in endothelial cells (fig. 5A-C). Exposure of endothelial cells to HEDS $(100 \mu \mathrm{g} / \mathrm{ml})$ caused the appearance within 1-5 min of a strong phosphorylation signal of Akt and eNOS. The increased phosphorylation signals persisted for up to $60 \mathrm{~min}$ (fig. $6 \mathrm{~A}-\mathrm{C}$ ). 


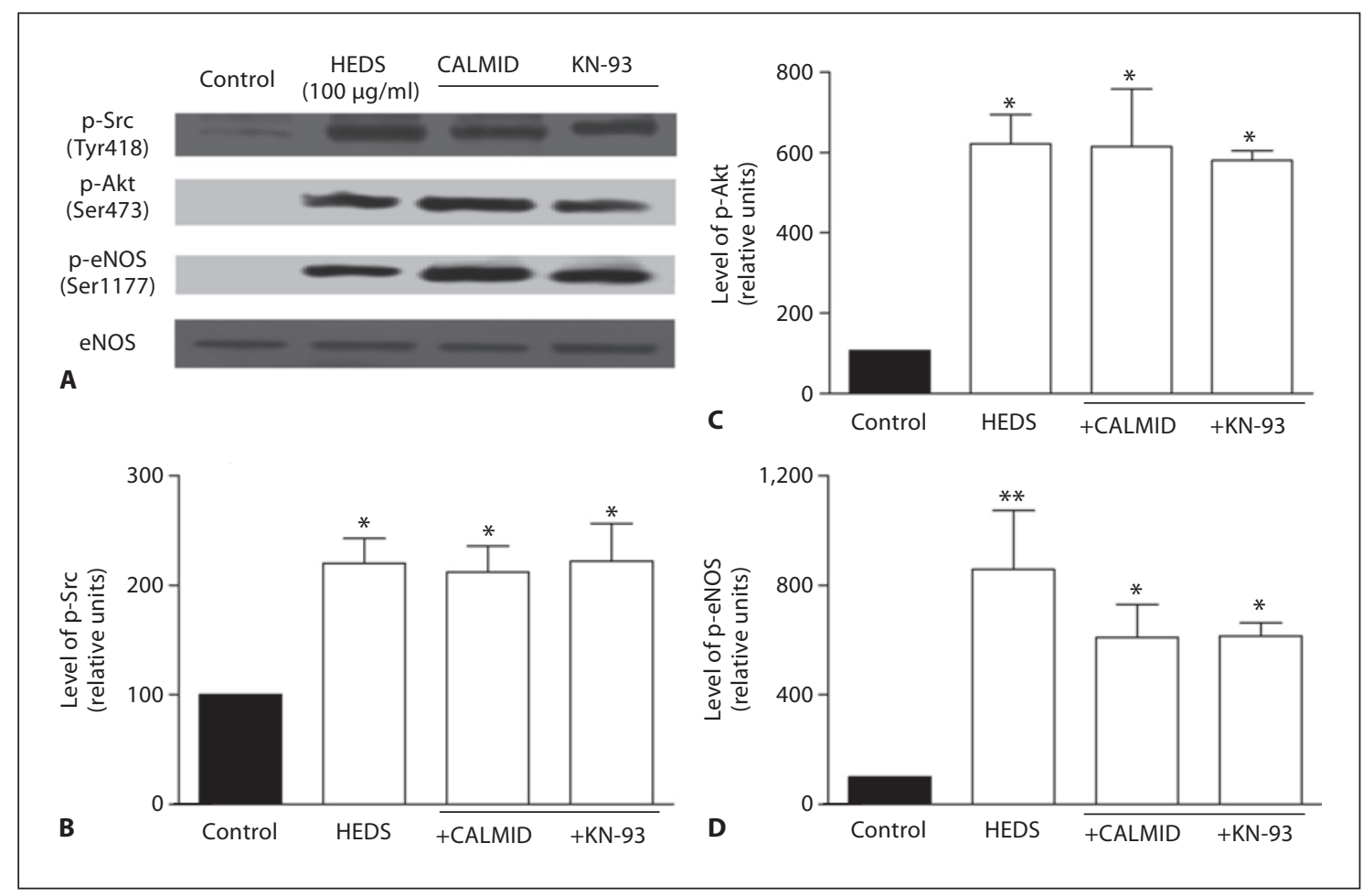

Fig. 7. Role of calmodulin and CaMKII in HEDS-induced phosphorylation of Src, Akt and eNOS in endothelial cells. Cells were incubated with either calmidazolium (CALMID, $10 \mu \mathrm{M}$ ) or KN-93 (10 $\mu \mathrm{M})$ for 30 min before the addition of HEDS $(100 \mu \mathrm{g} / \mathrm{ml})$. The levels of p-Src (B), p-Akt (C) and p-eNOS (D) were determined by Western blot analysis. A Representative immunoblots. Results are shown as means \pm SEM of 3-4 different experiments. ${ }^{*} \mathrm{p}<0.05$ and ${ }^{* *} \mathrm{p}<0.01$ versus control.

In addition, HEDS $(100 \mu \mathrm{g} / \mathrm{ml})$ enhanced the phosphorylation level of Src at Tyr418 (fig. 7A, B, 8A, B, 9A, B). Treatment of the cells with calmidazolium $(10 \mu \mathrm{M})$ or KN$93(10 \mu \mathrm{M})$ did not significantly affect the phophorylation of Src, Akt and eNOS (fig. 7B-D, respectively). In contrast, HEDS-induced phosphorylation of Akt and eNOS was abolished by MnTMPyP $(100 \mu \mathrm{M})$ and PEG-catalase (500 U/ml) (fig. 8C, D, respectively) and that of Src by MnTMPyP but not by PEG-catalase (fig. 8A, B). Also, the PI3-kinase inhibitor wortmannin prevented phosphorylation of Akt and eNOS (fig. 9A, C, D) but not that of Src (fig. 9A, B). The treatment with PP2 $(10 \mu \mathrm{M})$ reduced the phosphorylation level of Src (fig. 9A, B), almost abolished that of p-Akt (fig. 9A, C) and caused a small but significant reduction of p-eNOS (fig. 9A, D). These data indicate that ROS act as upstream mediators of Src kinase which induces activation of the PI3-kinase/Akt pathway leading to eNOS phosphorylation in response to HEDS.

In endothelial cells treated for only 5 min with HEDS $(100 \mu \mathrm{g} / \mathrm{ml})$, the increased phosphorylation level of Akt and eNOS was long-lasting. It reached a peak value within 25-55 min after washing and then returned gradually to baseline at $2 \mathrm{~h} 55 \mathrm{~min}$ (fig. $10 \mathrm{~A}-\mathrm{C}$ ).

\section{HEDS Inhibits the Contractile Responses Induced by}

\section{U46619 in Coronary Arteries}

Exposure of coronary artery rings to HEDS $(100 \mu \mathrm{g} /$ $\mathrm{ml}$ ) during 5, 30, $60 \mathrm{~min}$ or $3 \mathrm{~h}$ prior to the addition of cumulative concentrations of U46619 (1 nM to $1 \mu \mathrm{M})$ significantly reduced contractions in rings with endothelium (fig. 11). Incubation of rings with HEDS for only $5 \mathrm{~min}$ before washing was also associated with a reduced contraction to U46619 up to $55 \mathrm{~min}$ after washout (fig. 11C). The inhibitory effect of HEDS on contractile responses was prevented by L-NA (100 $\mu \mathrm{M}, 30 \mathrm{~min})$, indicating the involvement of the activation of eNOS (fig. 11A-D).

\section{HEDS has Antihypertensive Effects on SHR Rats}

Oral administration of HEDS induced a significant and dose-dependent decrease in mean arterial blood pres- 


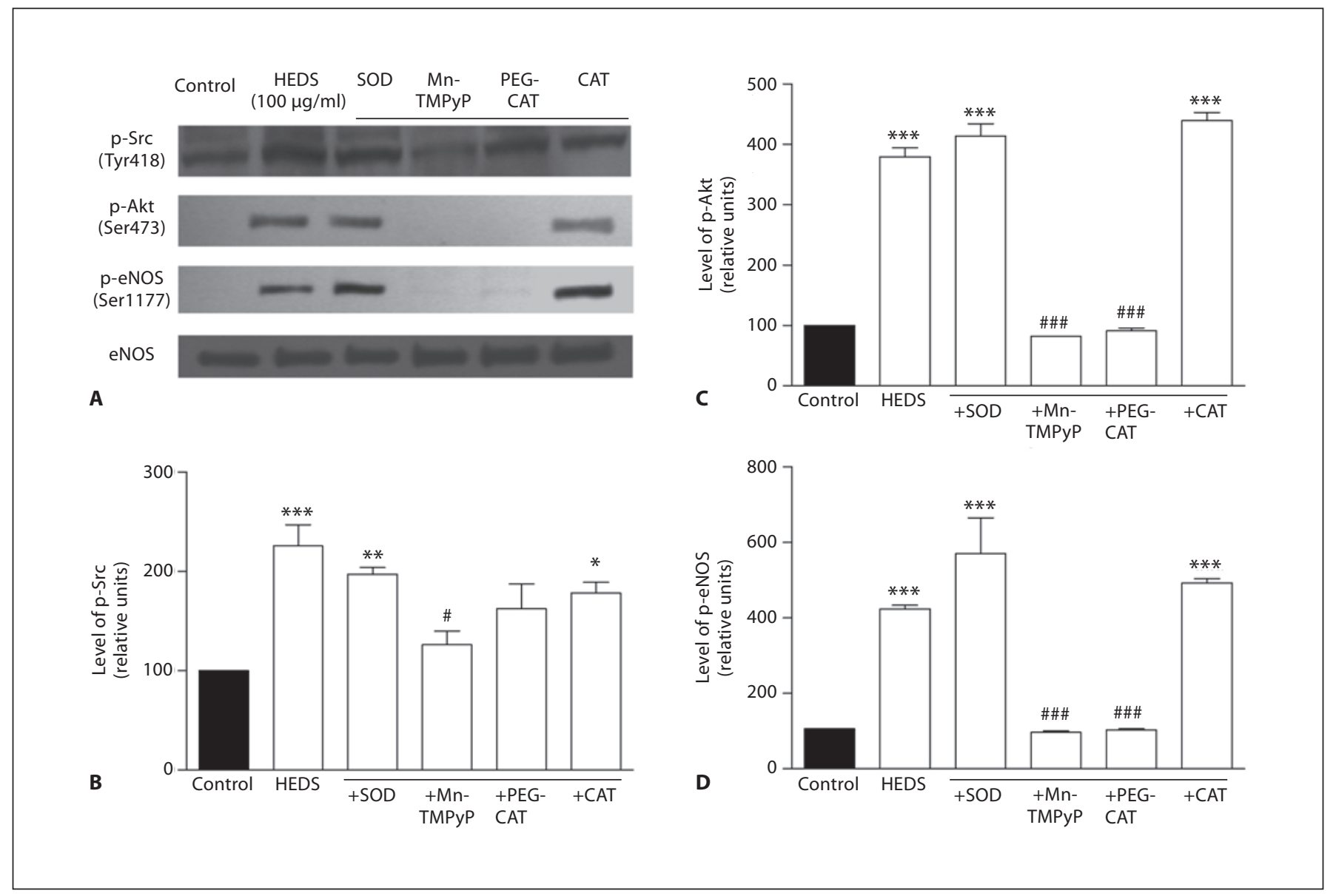

Fig. 8. Role of ROS in HEDS-induced phosphorylation of Src, Akt and eNOS in endothelial cells. Cells were incubated with either SOD (500 U/ml), MnTMPyP (100 $\mu \mathrm{M})$, PEG-catalase (PEG-CAT, $500 \mathrm{U} / \mathrm{ml})$, or catalase (CAT, $500 \mathrm{U} / \mathrm{ml})$ for $30 \mathrm{~min}$ before the addition of HEDS $(100 \mu \mathrm{g} / \mathrm{ml})$. The levels of p-Src, p-Akt and p-eNOS were determined by Western blot analysis. A Representative immunoblots. B-D Corresponding cumulative data. Results are shown as means \pm SEM of 3-4 different experiments. ${ }^{*} \mathrm{p}<0.05,{ }^{* *} \mathrm{p}<0.01$ and ${ }^{* * *} \mathrm{p}<0.001$ versus control; ${ }^{\#} \mathrm{p}<0.05$ and ${ }^{\# \# \#} \mathrm{p}<0.001$ versus HEDS.

sure of SHR rats $(-11.0 \pm 1.3,-17.6 \pm 1.4$ and $-23.5 \pm 1.5$ $\mathrm{mm} \mathrm{Hg}$ at 30,100 and $300 \mathrm{mg} / \mathrm{kg}$, respectively, $\mathrm{n}=5$ ) in comparison to vehicle (water, $-3.7 \pm 1.0 \mathrm{~mm} \mathrm{Hg}$ ).

\section{Discussion}

In the present study, standardized HEDS leaves extract was found to be a potent stimulus for endotheliumdependent relaxation in isolated porcine coronary arteries and eNOS activation in cultured porcine coronary endothelial cells. These responses are partially calmodulin-dependent and involve a ROS-dependent activation of Src kinase and subsequent PI3-kinase/Akt-dependent phosphorylation of eNOS at Ser1177 leading to smooth muscle relaxation.

HEDS caused potent endothelium-dependent relaxations in coronary artery rings which were reduced by L-NA and minimally affected by the combination of charybdotoxin plus apamin. However, the combination of L-NA, charybdotoxin and apamin abolished HEDS-induced relaxations. These findings indicate a major role for an L-NA-sensitive component of relaxation and also to some extent for an EDHF-mediated component. They are, at least in part, in agreement with a previous study performed using rat aorta rings [23].

In porcine coronary artery rings, HEDS-induced relaxations were not due to the formation of relaxing pros- 


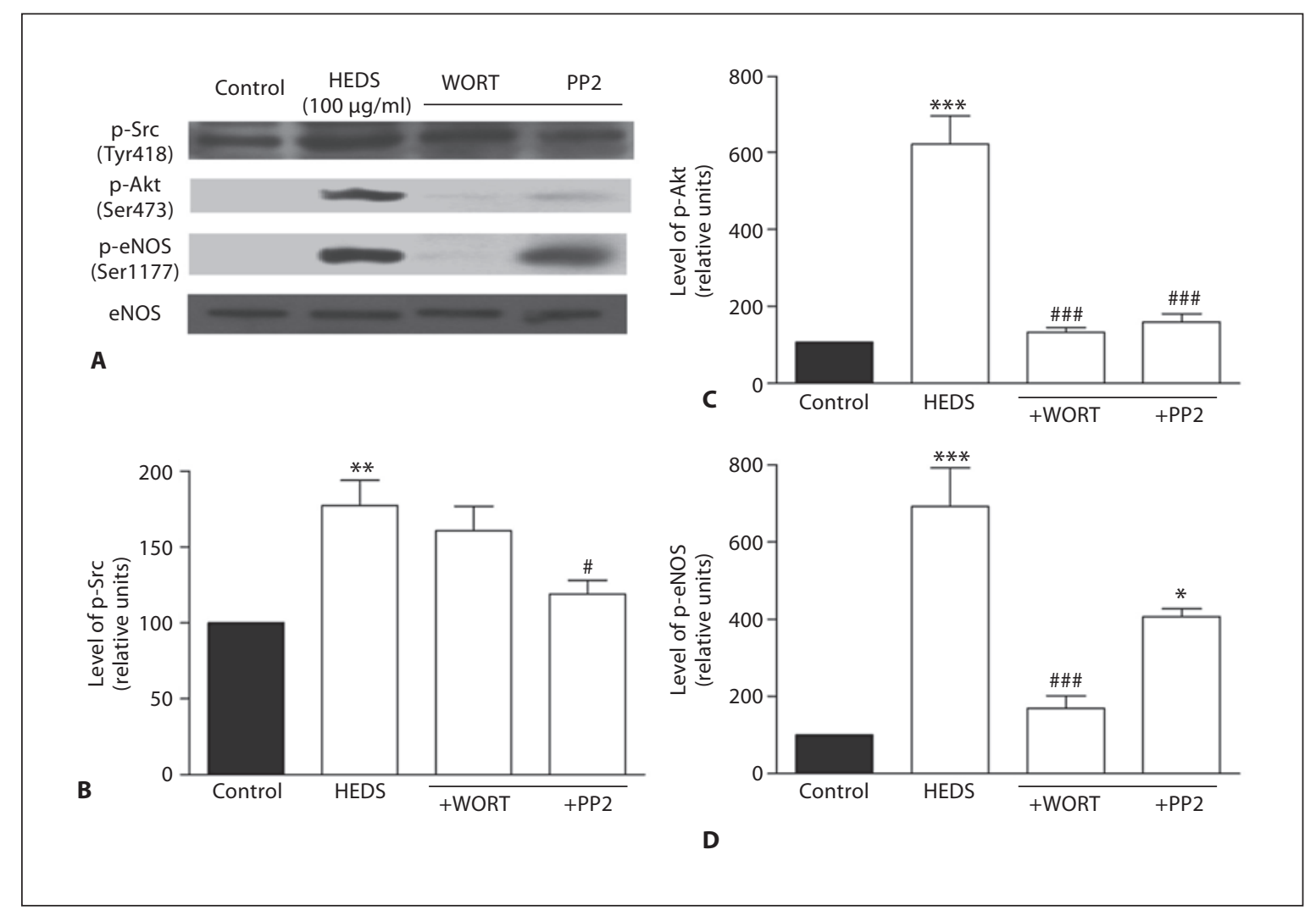

Fig. 9. Role of the PI3-kinase/Akt pathway and the Src kinase in HEDS-induced phosphorylation of Akt and eNOS in endothelial cells. Cells were incubated with either wortmannin (WORT, $30 \mathrm{nM}$ ) or PP2 (10 $\mu \mathrm{M})$ for 30 min before the addition of HEDS. The level of p-Src, p-Akt and p-eNOS was determined by Western blot analysis. A Representative immunoblots. B-D Corresponding cumulative data. Results are shown as means \pm SEM of 3-4 different experiments. ${ }^{* *} \mathrm{p}<0.01$ and ${ }^{* *} \mathrm{p}<0.001$ versus control; ${ }^{\#} \mathrm{p}<0.05$ and ${ }^{\# \# \#} \mathrm{p}<0.001$ versus HEDS.

tanoids or the activation of endothelial muscarinic receptors. Indeed, relaxations were slightly potentiated in the presence of indomethacin, a cyclooxygenase inhibitor, and also atropine, a muscarinic receptor antagonist. In contrast, NO-mediated relaxations induced by several substances or plant extracts in rat aortic rings have been shown to involve activation of muscarinic receptors [32-34]. In addition, acetylcholine is not able to relax porcine coronary artery rings [35] and can even induce a contractile response [36-39]. However, in agreement with the present findings, it has already been shown that endothelium-dependent modulation of vascular tone with acetylcholine or lionfish venom are potentiated by atropine in porcine coronary artery rings [40, 41]. A potentiating effect of indomethacin on HEDS-induced relaxations is observed. These findings suggest that arachidonic acid metabolites counteract the relaxation to HEDS [43].
Endothelial NO release can be activated by receptordependent and receptor-independent agonists as a consequence of an increase in the intracellular concentration of free $\mathrm{Ca}^{2+}$ and the association of a $\mathrm{Ca}^{2+} /$ calmodulin (CaM) complex with eNOS [44]. The subsequent NO formation and vasodilatation can be inhibited by CaM inhibitors [45]. In addition, calmodulin-dependent kinase, CaMKII, has been involved in the rapid phosphorylation of eNOS at Ser1177 and vasorelaxation after bradykinin stimulation, an effect inhibited by KN-93 [28, 46]. In the present study, the incubation with a calmodulin inhibitor, calmidazolium, caused approximately a $40 \%$ inhibition of HEDS-induced relaxation in coronary artery rings, whereas KN-93 was inactive. Also, none of the inhibitors affected the HEDS-induced phosphorylation of eNOS in cultured endothelial cells. 


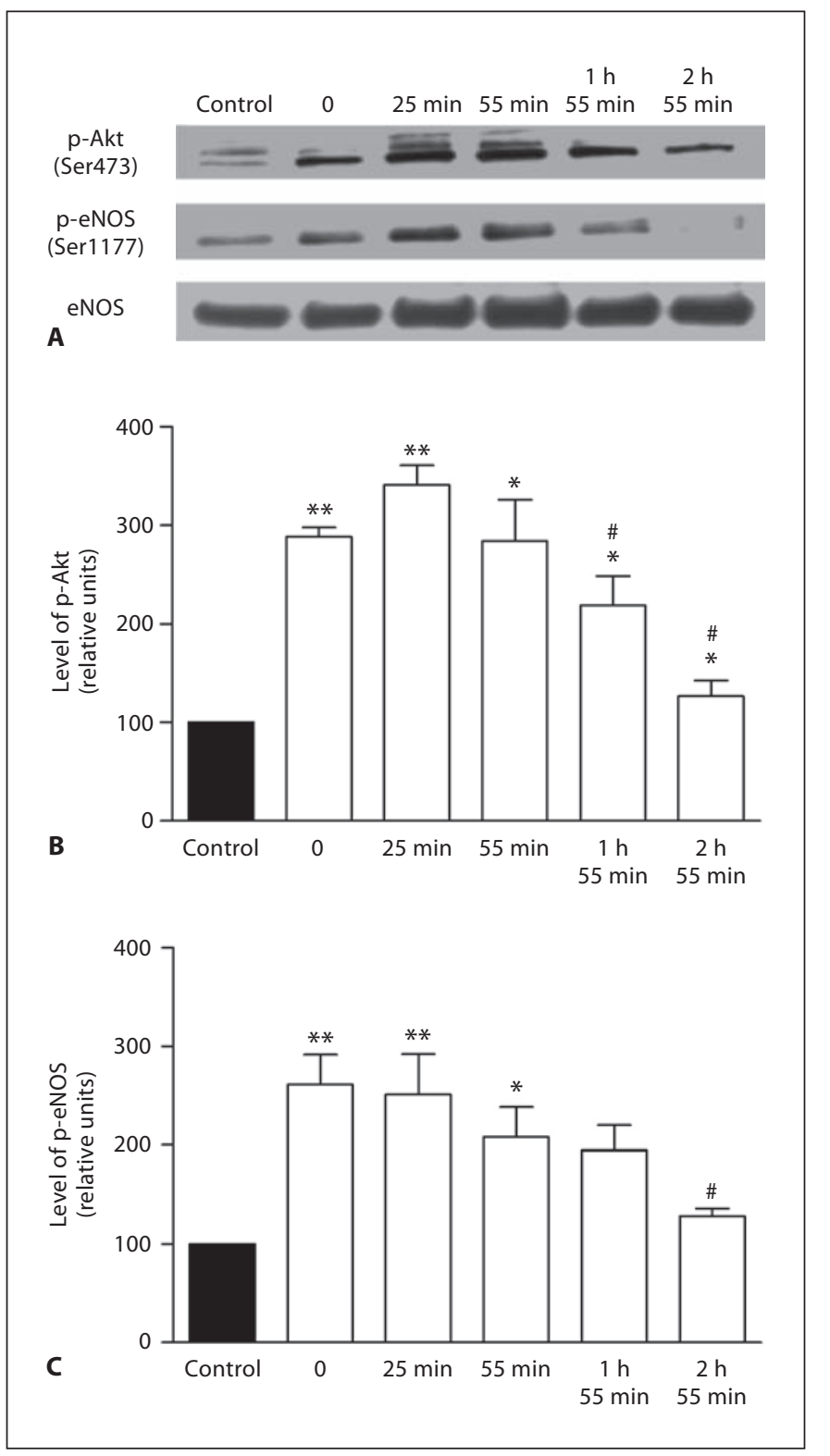

Fig. 10. Long-lasting effect of HEDS in coronary endothelial cells. The phosphorylation level of Akt (B) and eNOS (C) in endothelial cells was assessed at different times after incubation of the cells with HEDS $(100 \mu \mathrm{M})$ for only $5 \mathrm{~min}$ followed by washing. A Representative immunoblots. Results are shown as means \pm SEM of 3-4 different experiments. ${ }^{*} \mathrm{p}<0.05$ and ${ }^{* *} \mathrm{p}<0.01$ versus control; ${ }^{\#} \mathrm{p}<0.05$ versus HEDS $25 \mathrm{~min}$.

Altogether, these findings indicate that the HEDS-induced relaxant effect is partially dependent on $\mathrm{Ca}^{2+} / \mathrm{CaM}$ but not on CaMKII.

Previous studies have indicated that polyphenols are able to activate eNOS through two distinct mechanisms: an increase in intracellular $\mathrm{Ca}^{2+}$ and a phosphorylation of eNOS by the PI3-kinase/Akt pathway [1], a phenomenon which is strictly dependent upon the intracellular formation of superoxide anions in endothelial cells [19, 20, 47]. Therefore, experiments were performed to determine the role of ROS in HEDS-induced relaxations. In the presence of membrane-permeant analogs of either SOD or catalase (MnTMPyP and PEG-catalase, respectively), there was a strong reduction in the relaxations to HEDS, whereas native SOD and native catalase were inactive, indicating a key role of intracellular superoxide anions $\left(\mathrm{O}_{2}^{-}\right)$and to some extent of intracellular hydrogen peroxide $\left(\mathrm{H}_{2} \mathrm{O}_{2}\right)$. In addition, MnTMPyP and PEG-catalase also prevented HEDS-induced phosphorylation of eNOS at Ser1177. Moreover, direct evidence that HEDS is able to cause a NAC-, MnTMPyP- and PEG-catalase-sensitive pro-oxidant response was obtained with the redoxsensitive fluorescent probe DHE in coronary artery sections. Although the specific endothelial source of ROS remains to be determined, potential sources include NADPH oxidase, xanthine oxidase, cytochrome P450 monooxygenases and the polyphenolic compounds themselves [48-51]. A similar pathway involving an increased endothelial formation of superoxide anions has also been observed in eNOS activation in response to several other sources of polyphenols such as red wine and grape juices [15, 47, 52].

In endothelial cells, the formation of superoxide anion is able to activate the Src-PI3-kinase/Akt pathway leading to eNOS phosphorylation at Ser1177 in response to polyphenols [1]. This pathway can also be activated in response to several physiological stimuli including estrogens, shear stress, vascular endothelial growth factor, $\mathrm{H}_{2} \mathrm{O}_{2}$ and high-density lipoprotein [53-58]. HEDS caused activation of the PI3-kinase/Akt pathway in a redox-sensitive manner as indicated by the concentration- and time-dependent phosphorylation of Akt at Tyr418 and eNOS at Ser1177, and their inhibition by intracellular scavengers of ROS (MnTMPyP and PEG-catalase) and by wortmannin, an inhibitor of PI3-kinase, in endothelial cells and also in isolated coronary arteries. The present findings also indicate that Src kinase, a redox-sensitive protein kinase, acts upstream of the PI3-kinase/Akt pathway since the Src kinase inhibitor PP2 partially prevented HEDS-induced phosphorylation of Src, Akt and eNOS in endothelial cells and HEDS-induced endothelium-dependent relaxations in isolated coronary arteries. In addition, HEDS-induced phosphorylation of Src was prevented selectively by the intracellular scavenger of superoxide anions MnTMPyP but was not affected by 


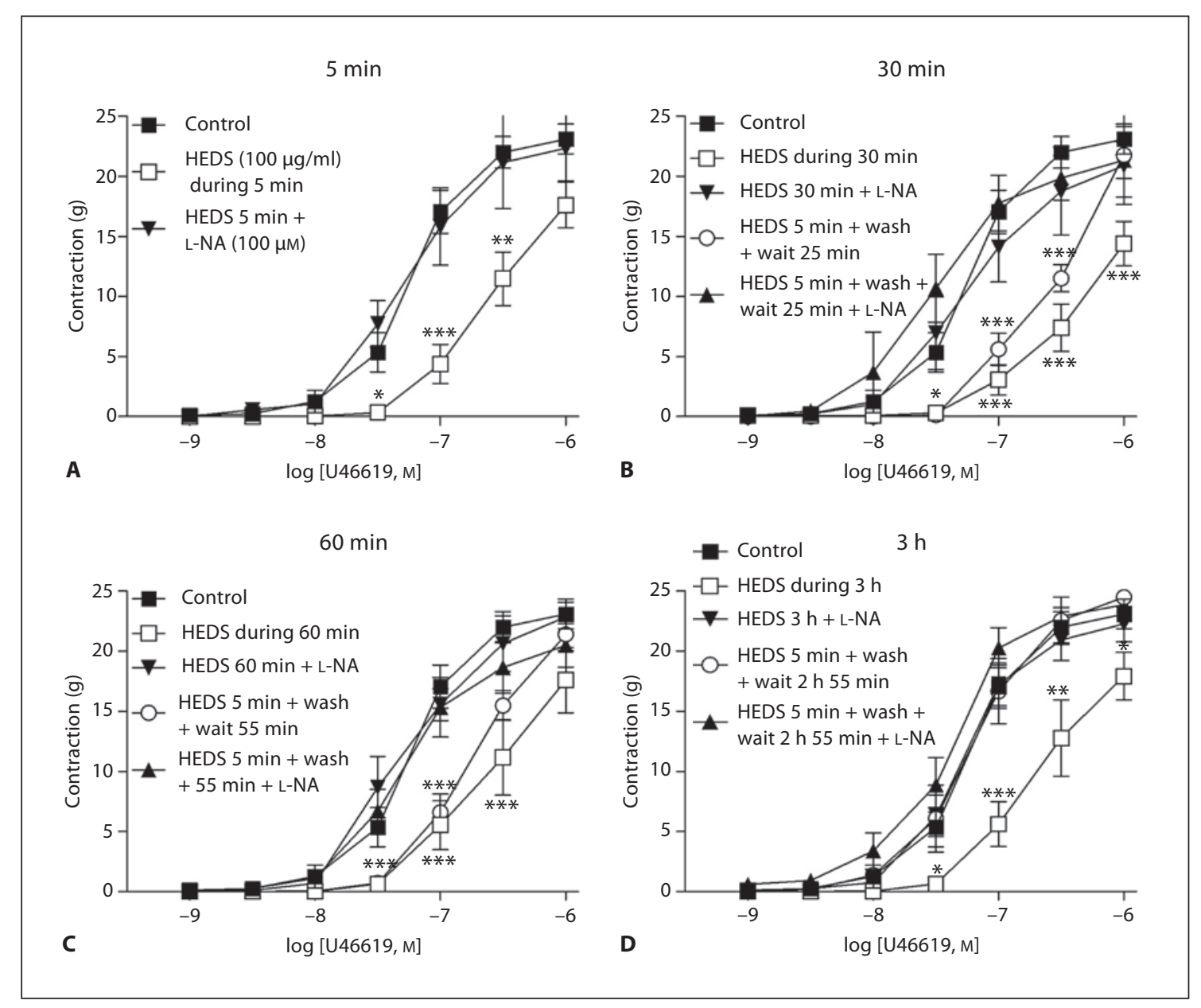

Fig. 11. Effect of HEDS on contractile responses in coronary artery rings with endothelium. The graph shows contractile curves to U46619 assessed either in the presence or absence of HEDS (100 $\mu \mathrm{g} / \mathrm{ml})$, with or without L-NA (100 $\mu \mathrm{M}, 30 \mathrm{~min})$, and at different times: $5 \mathrm{~min}(\mathbf{A}), 30 \mathrm{~min}(\mathbf{B}), 60 \mathrm{~min}(\mathbf{C})$ and $3 \mathrm{~h}$ (D). As indicated, some intact rings were exposed to HEDS $5 \mathrm{~min}$ before washout followed by a resting period before U46619-induced contractions. Results are shown as means \pm SEM of 6 different experiments. ${ }^{*} \mathrm{p}<0.05,{ }^{*} \mathrm{p}<0.01$ and ${ }^{* * *} \mathrm{p}<0.001$ for inhibitory effect versus control.

PEG-catalase, whereas both types of scavengers prevented phosphorylation of Akt and eNOS. This suggests that $\mathrm{O}_{2}^{-}$seems to play a more important role in the activation of Src. Additionally, $\mathrm{O}_{2}^{-}$can be partially converted to $\mathrm{H}_{2} \mathrm{O}_{2}$ and together they contribute to a potent activation of the PI3-kinase/Akt pathway [58].

Although polyphenols caused a modest pro-oxidant signal in endothelial cells, they did not induce the formation of ROS in the vascular smooth muscle of coronary arteries. In vascular smooth cells, it was reported that polyphenols prevented the growth factor-induced NADPH oxidase-dependent formation of ROS [59]. Moreover, they are able to scavenge superoxide anions, peroxyl radicals, hydroxyl radicals and peroxynitrite [60-62], to prevent the expression of pro-oxidant enzymes, such as $\mathrm{NADPH}$ oxidase and xanthine oxidase and to increase that of antioxidant enzymes such as catalase [63, 64].

HEDS induced long-lasting activation of eNOS even after short-term exposure to the extract. Within 1-5 min, HEDS caused the phosphorylation of eNOS at Ser1177 in endothelial cells. Moreover, the changes in the phosphorylation level of eNOS at Ser1177 were maintained for at least $3 \mathrm{~h}$ in the presence of HEDS and $55 \mathrm{~min}$ after a 5 -min exposure period to HEDS. This effect was followed by a slow decline of eNOS phosphorylation level to near baseline levels. In addition, HEDS caused a similar time- 
dependent inhibition of U46619-induced contractions in coronary artery rings.

The ability of HEDS to induce a decrease in blood pressure in SHR rats is in agreement with previous observations [23] and indicates that, like other polyphenol-rich extracts [1], HEDS could be of interest for the treatment of hypertensive states.

In summary, the present study indicates that HEDS causes an acute and potent activation of the NO pathway in endothelial cells from coronary arteries and that this effect involves both the calmodulin-dependent (but not CaMKII-dependent) and ROS/PI3 kinase/Akt-dependent activation of eNOS. These mechanisms could help explain the antihypertensive effects of HEDS in SHR rats.

\section{Acknowledgement}

This study was supported in part by a fellowship from CAPESBrazil.

\section{References}

$>_{1}$ Stoclet JC, Chataigneau T, Ndiaye M, Oak MH, El Bedoui J, Chataigneau M, SchiniKerth VB: Vascular protection by dietary polyphenols. Eur J Pharmacol 2004;500: 299-313.

-2 Fito M, de la Torre R, Farre-Albaladejo M, Khymenetz O, Marrugat J, Covas MI: Bioavailability and antioxidant effects of olive oil phenolic compounds in humans: a review. Ann Ist Super Sanita 2007;43:375-381.

3 Scalbert A, Manach C, Morand C, Remesy C, Jimenez L: Dietary polyphenols and the prevention of diseases. Crit Rev Food Sci Nutr 2005;45:287-306.

4 Curin Y, Andriantsitohaina R: Polyphenols as potential therapeutical agents against cardiovascular diseases. Pharmacol Rep 2005; 57(suppl):97-107.

5 Ruf JC: Overview of epidemiological studies on wine, health and mortality. Drugs Exp Clin Res 2003;29:173-179.

-6 Takahashi R, Ohmori R, Kiyose C, Momiyama Y, Ohsuzu F, Kondo K: Antioxidant activities of black and yellow soybeans against low density lipoprotein oxidation. J Agric Food Chem 2005;53:4578-4582.

-7 Santangelo C, Vari R, Scazzocchio B, Di Benedetto R, Filesi C, Masella R: Polyphenols, intracellular signalling and inflammation. Ann Ist Super Sanita 2007;43:394-405.

$>8$ Ouyang P, Peng WL, Xu DL, Lai WY, Xu AL: Green tea polyphenols inhibit advanced glycation end product-induced rat vascular smooth muscle cell proliferation. Di Yi Jun Yi Da Xue Xue Bao 2004;24:247-251.

9 Iijima K, Yoshizumi M, Ouchi Y: Effect of red wine polyphenols on vascular smooth muscle cell function - molecular mechanism of the 'French paradox'. Mech Ageing Dev 2002;123:1033-1039.

-10 Lo HM, Hung CF, Huang YY, Wu WB: Tea polyphenols inhibit rat vascular smooth muscle cell adhesion and migration on collagen and laminin via interference with cellECM interaction. J Biomed Sci 2007; 14:637645. de Lange DW, Verhoef S, Gorter G, Kraaijenhagen RJ, van de Wiel A, Akkerman JW: Polyphenolic grape extract inhibits platelet activation through PECAM-1: an explanation for the French paradox. Alcohol Clin Exp Res 2007;31:1308-1314.

12 Nardini M, Natella F, Scaccini C: Role of dietary polyphenols in platelet aggregation. A review of the supplementation studies. Platelets $2007 ; 18: 224-243$.

13 Lo CW, Huang HP, Lin HM, Chien CT, Wang CJ: Effect of Hibiscus anthocyaninsrich extract induces apoptosis of proliferating smooth muscle cell via activation of P38 MAPK and p53 pathway. Mol Nutr Food Res 2007;51:1452-1460.

14 Carluccio MA, Siculella L, Ancora MA, Massaro M, Scoditti E, Storelli C, Visioli F, Distante A, De Caterina R: Olive oil and red wine antioxidant polyphenols inhibit endothelial activation: antiatherogenic properties of Mediterranean diet phytochemicals. Arterioscler Thromb Vasc Biol 2003;23:622629.

15 Anselm E, Chataigneau M, Ndiaye M, Chataigneau T, Schini-Kerth VB: Grape juice causes endothelium-dependent relaxation via a redox-sensitive Src- and Akt-dependent activation of eNOS. Cardiovasc Res 2007;73: 404-413.

16 Corder R, Mullen W, Khan NQ, Marks SC, Wood EG, Carrier MJ, Crozier A: Oenology: red wine procyanidins and vascular health. Nature 2006;444:566.

17 Yamada H, Watanabe H: Tea polyphenols in preventing cardiovascular diseases. Cardiovasc Res 2007;73:439-440.

18 Mombouli JV, Vanhoutte PM: Endothelial dysfunction: from physiology to therapy. J Mol Cell Cardiol 1999;31:61-74.

19 Ndiaye M, Chataigneau T, Chataigneau M, Schini-Kerth VB: Red wine polyphenols induce EDHF-mediated relaxations in porcine coronary arteries through the redox-sensitive activation of the PI3-kinase/Akt pathway. Br J Pharmacol 2004;142:1131-1136.
20 Ndiaye M, Chataigneau M, Lobysheva I, Chataigneau T, Schini-Kerth VB: Red wine polyphenol-induced, endothelium-dependent NO-mediated relaxation is due to the redox-sensitive PI3-kinase/Akt-dependent phosphorylation of endothelial NO-synthase in the isolated porcine coronary artery. FASEB J 2005;19:455-457.

21 Sehnem A: Flora Ilustrada Catarinense. Itajaí, Herbário Barbosa Rodrigues, 1978.

22 Tryon RM, Tryon A: Ferns and Allied Plants with Special Reference to Tropical America. New York, Springer, 1982, p 857.

23 Rattmann YD, Crestani S, Lapa FR, Miguel OG, Marques MC, da Silva-Santos JE, Santos AR: Activation of muscarinic receptors by a hydroalcoholic extract of Dicksonia sellowiana Presl. HooK (Dicksoniaceae) induces vascular relaxation and hypotension in rats. Vascul Pharmacol 2009;50:27-33.

24 Tidwell WD, Rushforth SR, Simper AD: Precretaceous flowering plants: further evidence from Utah. Science 1970;170:547-548.

25 Rogge GD, Viana AM, Randi AM: Cryopreservation of spores of Dicksonia sellowiana: an endangered tree fern indigenous to South and Central America. Cryo Letters 2000;21:223-230.

26 Marquesini NR: Plantas usadas como medicinais pelos índios do Paraná e Santa Catarina, Sul do Brasil: Guarani, Kaingãng, Xokleng, Ava-Guarani, Kraô e Cayua; tese, Setor de Ciências da Saúde, Universidade Federal do Paraná, Curitiba, 1995, p 290.

$\checkmark 27$ Miller FJJ, Gutterman D, Rios C, Heistad D, Davidson B: Superoxide production in vascular smooth muscle contributes to oxidative stress and impaired relaxation in atherosclerosis. Circ Res 1998;82:1298-1305.

28 Fleming I, Fisslthaler B, Dimmeler S, Kemp BE, Busse R: Phosphorylation of $\operatorname{Thr}(495)$ regulates $\mathrm{Ca}(2+)$ /calmodulin-dependent endothelial nitric oxide synthase activity. Circ Res 2001;88:E68-E75. 
-29 Dimmeler S, Fleming I, Fisslthaler B, Hermann C, Busse R, Zeiher AM: Activation of nitric oxide synthase in endothelial cells by Akt-dependent phosphorylation. Nature 1999;399:601-605.

-30 Yoshizumi M, Abe J, Haendeler J, Huang Q, Berk B: Src and Cas mediate JNK activation but not ERK1/2 and p38 kinases by reactive oxygen species. J Biol Chem 2000;275:1170611712.

31 Haynes M, Li L, Sinha D, Russell K, Hisamoto K, Baron R, Collinge M, Sessa WC, Bender JR: Src kinase mediates phosphatidylinositol 3-kinase/Akt-dependent rapid endothelial nitric-oxide synthase activation by estrogen. J Biol Chem 2003;278:21182123.

- 32 Koh SB, Kang MH, Kim TS, Park HW, Park CG, Seong YH, Seong HJ: Endothelium-dependent vasodilatory and hypotensive effects of Crotalaria sessiliflora L. in rats. Biol Pharm Bull 2007;30:48-53.

-33 Kwan CY, Zhang WB, Sim SM, Deyama T, Nishibe S: Vascular effects of Siberian ginseng (Eleutherococcus senticosus): endothelium-dependent NO- and EDHF-mediated relaxation depending on vessel size. Naunyn Schmiedebergs Arch Pharmacol 2004;369: 473-480.

34 Vasques CA, Cortes SF, Silva MS, de Medeiros IA: Muscarinic agonist properties of the hydrobutanol extract from aerial parts of Waltheria viscosissima St. Hil. (Sterculiaceae) in rats. Phytother Res 1999;13:312-317.

- 35 Harasawa Y, Kimura M, Ohno Y, Hayashi S: Coronary endothelium is responsive to bradykinin and arachidonate but not to acetylcholine. Arch Int Pharmacodyn Ther 1989; 302:196-208.

-36 Weirich J, Dumont L, Fleckenstein-Grun G: Contribution of capacitative and non-capacitative $\mathrm{Ca}^{2+}$-entry to $\mathrm{M} 3$-receptor-mediated contraction of porcine coronary smooth muscle. Cell Calcium 2005;38:457-467.

- 37 Yamanoue T, Brum JM, Estafanous FG, Khairallah PA, Ferrario CM: Fentanyl attenuates porcine coronary arterial contraction through M3-muscarinic antagonism. Anesth Analg 1993;76:382-390.

- 38 Tsuchida H, Schubert A, Estafanous FG, Brum JM, Murray PA: Sigma receptor activation does not mediate fentanyl-induced attenuation of muscarinic coronary contraction. Anesth Analg 1996;82:982-987.

-39 Yang XP, Fu SX, Li YS: Effects of m-nisoldipine on anoxia-potentiated histamine and acetylcholine-induced contractions of the porcine isolated coronary artery. Zhongguo Yao Li Xue Bao 1990;11:513-517.

40 Church JE, Hodgson WC: Adrenergic and cholinergic activity contributes to the cardiovascular effects of lionfish (Pterois volitans) venom. Toxicon 2002;40:787-796.
41 Myers PR, Banitt PF, Guerra R Jr, Harrison DG: Role of the endothelium in modulation of the acetylcholine vasoconstrictor response in porcine coronary microvessels. Cardiovasc Res 1991;25:129-137.

42 Dusting GJ, Moncada S, Vane JR: Prostacyclin (PGI2) is a weak contractor of coronary arteries of the pig. Eur J Pharmacol 1977;45: 301-304.

43 Vanhoutte PM, Tang EH: Endothelium-dependent contractions: when a good guy turns bad! J Physiol 2008;586:5295-5304

44 Fleming I, Busse R: Signal transduction of eNOS activation. Cardiovasc Res 1999;43: 532-541.

45 Busse R, Mulsch A: Calcium-dependent nitric oxide synthesis in endothelial cytosol is mediated by calmodulin. FEBS Lett 1990; 265:133-136.

46 Cai H, Liu D, Garcia JG: CaM Kinase II-dependent pathophysiological signalling in endothelial cells. Cardiovasc Res 2008;77:30-34.

- 47 Ndiaye M, Chataigneau T, Andriantsitohaina R, Stoclet JC, Schini-Kerth VB: Red wine polyphenols cause endothelium-dependent EDHF-mediated relaxations in porcine coronary arteries via a redox-sensitive mechanism. Biochem Biophys Res Commun 2003; 310:371-377.

48 Roques SC, Landrault N, Teissedre PL, Laurent C, Besancon P, Rouanet JM, Caporiccio $\mathrm{B}$ : Hydrogen peroxide generation in $\mathrm{CaCo}-2$ cell culture medium by addition of phenolic compounds: effect of ascorbic acid. Free Radic Res 2002;36:593-599.

49 Long LH, Clement MV, Halliwell B: Artifacts in cell culture: rapid generation of hydrogen peroxide on addition of (-)-epigallocatechin, (-)-epigallocatechin gallate, (+)-catechin, and quercetin to commonly used cell culture media. Biochem Biophys Res Commun 2000;273:50-53.

50 Ullrich V, Bachschmid M: Superoxide as a messenger of endothelial function. Biochem Biophys Res Commun 2000;278:1-8.

51 Sarr M, Chataigneau M, Martins S, Schott C, El Bedoui J, Oak MH, Muller B, Chataigneau T, Schini-Kerth VB: Red wine polyphenols prevent angiotensin II-induced hypertension and endothelial dysfunction in rats: role of NADPH oxidase. Cardiovasc Res 2006;71: 794-802.

52 Madeira SV, Auger C, Anselm E, Chataigneau M, Chataigneau T, Soares de Moura R, Schini-Kerth VB: eNOS activation induced by a polyphenol-rich grape skin extract in porcine coronary arteries. J Vasc Res 2009;46:406-416.

53 Corson MA, James NL, Latta SE, Nerem RM, Berk BC, Harrison DG: Phosphorylation of endothelial nitric oxide synthase in response to fluid shear stress. Circ Res 1996;79:984-991.

54 Garcia-Cardena G, Fan R, Stern DF, Liu J, Sessa WC: Endothelial nitric oxide synthase is regulated by tyrosine phosphorylation and interacts with caveolin-1. J Biol Chem 1996; 271:27237-27240.
55 Michell BJ, Griffiths JE, Mitchelhill KI, Rodriguez-Crespo I, Tiganis T, Bozinovski S, de Montellano PR, Kemp BE, Pearson RB: The Akt kinase signals directly to endothelial nitric oxide synthase. Curr Biol 1999;9:845848.

56 Harris MB, Ju H, Venema VJ, Liang H, Zou R, Michell BJ, Chen ZP, Kemp BE, Venema RC: Reciprocal phosphorylation and regulation of endothelial nitric-oxide synthase in response to bradykinin stimulation. J Biol Chem 2001;276:16587-16591.

57 Mineo C, Yuhanna IS, Quon MJ, Shaul PW: High density lipoprotein-induced endothelial nitric-oxide synthase activation is mediated by Akt and MAP kinases. J Biol Chem 2003;278:9142-9149.

58 Thomas SR, Chen K, Keaney JF Jr: Hydrogen peroxide activates endothelial nitric-oxide synthase through coordinated phosphorylation and dephosphorylation via a phosphoinositide 3-kinase-dependent signaling pathway. J Biol Chem 2002;277:6017-6024.

59 Oak MH, Chataigneau M, Keravis T, Chataigneau T, Beretz A, Andriantsitohaina R, Stoclet JC, Chang SJ, Schini-Kerth VB: Red wine polyphenolic compounds inhibit vascular endothelial growth factor expression in vascular smooth muscle cells by preventing the activation of the p 38 mitogen-activated protein kinase pathway. Arterioscler Thromb Vasc Biol 2003;23:1001-1007.

$60 \mathrm{Hu}$ JP, Calomme M, Lasure A, De Bruyne T, Pieters L, Vlietinck A, Vanden Berghe DA: Structure-activity relationship of flavonoids with superoxide scavenging activity. Biol Trace Elem Res 1995;47:327-331.

-61 Sato M, Maulik G, Ray PS, Bagchi D, Das DK: Cardioprotective effects of grape seed proanthocyanidin against ischemic reperfusion injury. J Mol Cell Cardiol 1999;31:12891297.

62 Aldini G, Carini M, Piccoli A, Rossoni G, Facino RM: Procyanidins from grape seeds protect endothelial cells from peroxynitrite damage and enhance endothelium-dependent relaxation in human artery: new evidences for cardio-protection. Life Sci 2003; 73:2883-2898.

- 63 Ying CJ, Xu JW, Ikeda K, Takahashi K, Nara Y, Yamori Y: Tea polyphenols regulate nicotinamide adenine dinucleotide phosphate oxidase subunit expression and ameliorate angiotensin II-induced hyperpermeability in endothelial cells. Hypertens Res 2003;26: 823-828.

64 Lin JK, Chen PC, Ho CT, Lin-Shiau SY: Inhibition of xanthine oxidase and suppression of intracellular reactive oxygen species in HL-60 cells by theaflavin-3,3'-digallate, (-)-epigallocatechin-3-gallate, and propyl gallate. J Agric Food Chem 2000;48:27362743. 